УДК: 378.091.12:001.894.2

DOI:

Уляна Ткаченко, аспірант

Хмельницької гуманітарно-педагогічної академї

\title{
ФОРМУВАННЯ ІННОВАЦИЙНОЇ КУЛЬТУРИ ВИКЛАДАЧА ЗАКЛАДУ ВИЩОї ОСВІТИ
}

У статті розкрито особливості інноваційної культури викладача закладу вищої освіти, визначено ї̈ сутність, сучасні підходи, щзо проявляються у здатності об'єктивно оиінювати нові ідеї та творчо їх використовувати. Акцентовано на основних функиіях інноваційної культури: пізнавально-перетворювальній, ціннісно-нормативній, комунікативній, інтеграчійній та ін. Висвітлено основні компоненти вищезазначеного поняття: аксіологічний, інноваційно-технологічний, кооперативно-діяльнісний, комунікативний та ін. Запропоновано методи формування інновачійної культури викладача, як-от: полілог, дискусія, рольові ігри тощчо.

Ключові слова: інноваційна культура викладача; заклад вищої освіти; функиії інноваційної культури; компоненти інновачійної культури; методи формування інноваційної культури.

Jim. 5.

Ulyana Tkachenko, Postgraduate Student Khmelnytskiy Humanitarian-Pedagogical Academy

\section{FORMATION OF INNOVATION CULTURE OF THE TEACHER OF HIGHER EDUCATION INSTITUTION}

The article reveals the peculiarities of the innovation culture of the teacher of higher education institution, defines its essence, modern approaches, which are manifested in the ability to objectively evaluate new ideas and creatively use them. It is focused on the main functions of innovation culture: cognitive-transformative, valuenormative, communicative, integrative and others. The basic components of the above mentioned concept have been highlighted: axiological, innovation-technological, cooperative-activity, communicative, etc. The methods of formation of innovation culture of the teacher are offered; they are: polylogue, discussion, role-playing games, etc.

Thus, innovation teaching of high school teachers is of great importance in the formation of innovative culture, convince in the importance of such areas of development of professional qualities of the pedagogue, as emotional thinking, formation of the new type of communication and communicative abilities, development of the ability for internal dialogue as a basis of self-knowledge, problems of communication, lability (variability) of its ways, change of roles.

Innovation culture is necessary for the effective professional activity of a high school teacher, as it provides innovative character of activity, active participation in innovative educational processes and includes a set of knowledge, skills, methods, pedagogical activities for the generation, development and implementation of innovations into professional activity.

Keywords: teacher's innovation culture; an institution of higher education; functions of innovation culture; components of innovation culture; methods of formation of innovation culture.

П остановка проблеми в загальному вигляді. Нова українська держава, глобалізована національна спільнота потребують оновлення засад педагогічної діяльності, нового професійного мислення, носій якого, викладач вищої школи, має виявляти високий рівень мотивації та професійної готовності до інноваційних зрушень.

В умовах євроінтеграції пріоритетним завданням $є$ формування інноваційної культури викладача закладу вищої освіти, що включає в себе систему знань, умінь, навичок, особистих якостей для ефективного впровадження інновацій в підготовці майбутніх компетентних фахівців.

У законі України "Про інноваційну діяльність" інноваційна культура визначається аспектом інноваційного потенціалу, який визначає ступінь освітньої, загальнокультурної і психологічної готовності особистості до творчого впровадження в життя інноваційних ідей розвитку суспільства [2].

На сучасному етапі важливою складовою діяльності закладу вищої освіти $є$ створення освітнього середовища 3 інноваційним потенціалом, шо передбачає модернізацію кадрового забезпечення, підвищення рівня професійної майстерності викладачів, оволодіння ними сучасними інноваціями, дослідницькими процедурами, а також організаційно-методичними та змістовими змінами в освіті. 
Аналіз останніх досліджень і публікацій. Феномен інноваційної культури як складової загальної культури вивчали В. Буйко, Б. Лісін, А. Ніколаєв. Педагогічні умови та методики іï формування розглянуто в працях В. Авраменко, О. Аматьєвої, Н. Гавриш, Р. Миленкової, Ю. Ситник. Соціально-психологічні детермінанти розвитку інноваційної культури та їх вплив на формування особистісних якостей науковопедагогічних працівників висвітлено в дослідженнях О. Єфросініної, А. Кальянова, В. Носкова. Сучасні наукові дослідження визначають інноваційну культуру, як комплексну готовність різного рівня щодо використання інновацій. Як відзначають вітчизняні вчені, у найближчому майбутньому вносити зміни у традиційну парадигму освіти зможуть тільки люди, які мають особливі якості, а саме: системне бачення і повне усвідомлення дослідноекспериментальної роботи; постійна готовність до сприйняття нової інформації, уміння виділяти і вирішувати науково-педагогічні проблеми у світлі завдань вищого навчального закладу; володіють мистецтвом рефлексії [2].

Мета статті - розкрити особливості формування інноваційної культури викладача закладу вищої освіти, показати їі функції, компоненти, методи.

Виклад основного матеріалу. У сучасній науковій літературі інноваційна культура розглядається як готовність особистості до існування в доцільно організованому просторі життєдіяльності, елементами якого є інноваційні цінності, здатність їх ефективно використовувати у підготовці майбутніх фахівців.

В. Балабанов під інноваційною культурою розуміє особливу форму культури, що становить нову реальність, яка виникла завдяки прагненню суспільства до духовного й матеріального самооновлення [3].

Згідно з визначенням І. Циркуна, інноваційна культура - система, що включає всю сукупність нормативів, що детермінують якість інноваційної діяльності, і виконує такі функції: раціональнопраксиологічну. організаційно-впорядковувальну, описово-пояснювальну, прогностично-управлінську, евристико-пізнавальну та комунікативнотрансляційну [2].

У наш час викладач закладу вищої освіти здійснює свою діяльність в умовах модернізації форм, методів, технологій навчання. У зв'язку з цим інноваційна культура викладача потребує переосмислення основних положень освітнього процесу, усвідомлений вибір професійної позиції, що буде підгрунтям подальшої його кар'єри.
На основі наукових досліджень нами визначено, що інноваційна культура викладача закладу вищої освіти формується на особистісному та фаховому рівнях. У контексті особистості - це ціннісні орієнтації, система мотивів, знань, умінь, навичок, позитивно-оцінне ставлення до новацій, нових ідей, підтримка їх та впровадження в навчально-виховний процес закладу вищої освіти. На рівні фахівця інноваційна культура зорієнтована на розвиток освітнього середовища 3 метою досягнення високих результатів. Професійно-педагогічна культура викладача 3 інноваційним спрямуванням направлена на діяльність з створення, освоєння та впровадження в освітній процес навчального закладу інноваційного середовища [1]. Ми погоджуємося з думкою науковців, що викладач, якому притаманна інноваційна культура, повинен мати певні особистісно-професійні якості: усвідомлення смислу і цілей освітньої діяльності в контексті актуальних педагогічних проблем сучасної вищої школи; здатність визначати цілі освітнього процесу згідно потреб суспільства та проблем вищої освіти; здатність орієнтуватися у нововведеннях на основі особистісно-орієнтованої освіти; вміння вчасно змінювати освітній процес у відповідності до інноваційної мети; володіння сучасними інноваційними технологіями, різноманітними формами мислення, оригінальними методиками, аналітичними уміннями; здатність до творчого пошуку, рефлексивної діяльності, до формування інновативності студентів, а також розуміння значущості особистих інноваційних експериментів та досліджень [3].

I.M. Дичківська визначає інноваційну культуру педагогічного працівника як систему освоєних особистістю педагогічних засобів, що забезпечують інноваційний спосіб діяльності, системоутворюючим елементом якого $є$ цінності інноваційного плану

Інноваційна культура викладача $€$ інтегративною системою, що включає сукупність знань, умінь, навичок, способів інноваційної педагогічної діяльності, усвідомлювані цінності інноваційної особистості, психологічні властивості інноваційного типу особистості педагогічних працівників та їхню інноваційну поведінку [2].

Сучасні дослідники (О. Аматьєва та Н. Гавриш) вважають, що інноваційна культура - це такий рівень професійності, який виявляється уздатності об'єктивно оцінювати нові ідеї, у готовності творчо освоювати і використовувати усвоїй роботі всенове, прогресивне [1].

3 метою визначення інноваційної культури необхідно враховувати іiі основні функції. Дослідники В. Носков, А. Кальянов, О. Сфросініна пропонують, зокрема, такі: 
- пізнавально-перетворювальна, що здійснює заходи теоретичної та організаційної діяльності;

- регулятивна, яка визначає важливу роль інновацій у розвитку суспільства та його соціальних інститутів;

- ціннісно-нормативна, що дає оцінку явищам у галузі інноваційної діяльності;

- комунікативна, яка передбачає спілкування та обмін досвідом;

- соціалізації, що розглядає інноваційну культуру крізь призму суспільних цінностей;

- прогностична, яка передбачає вивчення i прогнозування можливих шляхів і напрямів розвитку інноваційної культури в окремій галузі;

- інтеграційна, що поєднує інші різновиди культури в єдину культуру особистості [4].

Інноваційна культура ученими розглядається як сукупність таких взаємопов'язаних компонентів: аксіологічного, інноваційнотехнологічного, кооперативно-діяльнісного, комунікативного, особистісно-творчого [3].

Аксіологічний компонент інноваційної культури педагога - це сукупність педагогічних цінностей: оновлення професійно значущих знань, уявлень, переконань педагога. Вищезазначене є умовою і результатом інноваційно-педагогічної діяльності.

Інноваційно-технологічний компонент об'єднує способи інноваційно-педагогічної діяльності, для реалізації завдань управління інноваціями та самоврядування інноваційнопедагогічною діяльністю, до яких відносяться: аналітико-рефлексивні завдання; конструктивнопрогностичні; організаційно-діяльні; оціночноінформаційні; корекційно-регуляторні.

Кооперативно-діяльнісний компонент відображає культуру співпраці викладачів у спільній інноваційної діяльності.

Комунікативний компонент визначає культуру участі викладача в інформаційному обміні. В інноваційному процесі обсяг інформації багаторазово збільшується, зростає щільність інформаційного потоку і різноманітність даних, які педагог повинен засвоювати, класифікувати, аналізувати, виділити головне і другорядне, достовірні й сумнівні відомості. Комунікативний компонент включає в себе: розуміння ролі інформації в інноваційному процесі; позитивне ставлення до нових джерел інформації, в тому числі до ІКТ технологій.

Особистісно-творчий компонент забезпечує інтерпретацію педагогічних нововведень в індивідуально-педагогічній діяльності викладача: створення власного інноваційного досвіду, професійно-особистісну самореалізацію, врахування потреб і можливостей студентів тощо.
Компоненти інноваційної культури охоплюють аспекти оволодіння викладачем новими педагогічними цінностями, технологіями педагогічної діяльності, способами професійної взаємодії в нових умовах, рівнем участі в інформаційному обміні і новими можливостями професійно-творчої самореалізації [4].

Серед специфічних шляхів формування інноваційної культури педагога вищої школи на особливу увагу заслуговують методи рефлексивноінноваційного практикуму, запропоновані В. Сластьоніним і Л. Подимовою, як от: полілог, дискусія, рефлексивна інверсія, інтерв’ю. Суть означених методів полягає в їх принциповій інноваційній відкритості по відношенню до кожної педагогічної задачі у творчому розумінні.

Метод проблемно-рефлексивного полілогу забезпечує актуалізацію і розвиток творчих можливостей педагога прийняття інноваційних рішень.

Демонстрачійні рольові ігри проводяться частиною учасників групи перед рештою. Такі ігри використовують для стимулювання дискусії і для демонстрації тих чи інших навичок [5].

Метод позииійної дискусї дозволяє не лише сформувати банк даних про різні педагогічні інновації, але й забезпечити процес їх критичного аналізу. Механізм такої дискусії передбачає поділ групи на три частини.

Перша група зосереджує увагу на виробленні проекту майбутньої інновації, на своєму баченні та обгрунтуванні ㄲï. Друга група розробляє програму дій відповідно свого рішення. Завданням третьої групи $є$ аналіз та пошук компромісних шляхів вирішення проблеми.

Метод проектів. В проекті ідея зароджується, розгортається у вигляді задуму, переходить до плану діяльності, пошуку можливостей реалізації задуму та його здійснення найоптимальнішими засобами. У навчальному процесі у вищій школі педагогічне проектування здійснюється на різних організаційних рівнях: концептуальне проектування освітнього процесу на факультеті чи в університеті; проектування технологій вивчення різних дисциплін [3].

Висновки. Таким чином, інноваційне навчання викладачів вищої школи відіграє велике значення у формуванні інноваційної культури, особистісних якостей педагога, сприйнятливості до нововведень, нових ідей, розвитку комунікативних здібностей, творчого потенціалу, педагогічної ерудиції, високих соціально-адаптаційних можливостей.

Інноваційна культура $\epsilon$ ефективним компонентом професійної діяльності викладача 


\section{ПЕДАГОГІЧНІ УМОВИ ВИКОРИСТАННЯ ІННОВАЦЙНИХ ТЕХНОЛОГІЙ В ОСВІТНЬОМУ ПРОЦЕСІ ЗВО}

вищої школи, оскільки формує його інновативність, інноваційний потенціал, здатність створювати, сприймати та реалізовувати нововведення, координувати та регулювати інноваційні процеси в закладах вищої освіти.

Перспективи подальших розвідок у даному напрямі. Перспективи подальших розвідок щодо формування інноваційної культури викладача закладу вищої освіти ми вбачаємо у розробці моделі їі формування в освітньому процесі, позааудиторній діяльності, в процесі керівництва практикою студентів.

\section{ЛІТЕРАТУРА}

1. Вітвіцька С.С. Основи педагогіки вищої школи: методичний посібник. Київ, 2003.316 с.

2. Дичківська І.М. Інноваційні педагогічні технології: підручник. Київ, 2015. 304 с.

3. Козлова О.Г., Миленкова Р.В. Інноваційна культура: сутнісні характеристики: монографія. Суми, 2008. $140 \mathrm{c}$.
4. Ортинський В.Л. Педагогіка вищої школи: навчальний посібник. Київ, 2009. 472 с.

5. Щербань П.М. Навчально-педагогічні ігри: навчальний посібник. Київ, 2004. 240 с.

\section{REFERENCES}

1. Vitvitska, S.S. (2003). Osnovy pedahohiky vyshchoi shkoly: metodychnyi posibnyk [The fundamentals of Higher Education Pedagogy: A Toolkit]. Kyiv, 316p.[in Ukrainian].

2. Dychkivska, I.M. (2015). Innovatsiini pedahohichni tekhnolohii: pidruchnyk [Innovative pedagogical technologies: a textbook]. Kyiv, 304 p.[in Ukrainian].

3. Kozlova, O.H. \& Mylenkova, R.V. (2008). Innovatsiina kultura: sutnisni kharakterystyky: monohrafiia [Innovative culture: essential characteristics: a monograph]. Sumy, 140p. [in Ukrainian].

4. Ortynskyi, V.L. (2009). Pedahohika vyshchoi shkoly: navchalnyi posibnyk [Higher education pedagogy: a textbook]. Kyiv, 472 p. [in Ukrainian].

5. Shcherban, P.M. (2004). Navchalno-pedahohichni ihry: navchalnyi posibnyk [Educational and pedagogical games: a textbook]. Kyiv, 240 p. [in Ukrainian].

Стаття надійшла до редакції 23.12.2019

УДК: 371.134

DOI:

Лілія Бандура, аспірант ДВНЗ “Прикарпатський національний університет імені Василя Стефаника"

\section{ПЕДАГОГІЧНІ УМОВИ ВИКОРИСТАННЯ ІННОВАЦІЙНИХ ТЕХНОЛОГІЙ В ОСВІТНЬОМУ ПРОЦЕСІ ЗВО}

У статті розглянуто особливості використання інноваційних технологій в процесі навчання у вищій школі. Виконано аналіз науково-педагогічної літератури та документів, шо стосуються теми роботи. Висвітлено основні критерії гуманістичного навчання у $3 В О$ з використанням інновацій. Подано умови використання технологій та їх застосування зокрема, опрацьовано найпопулярніші класифікації інноваційних технологій різними науковиями. Презентовано нові авторські критерії для їх класифікаиії.

Ключові слова: інновачї; інновачійне навчання; інновачійні технологї; інтерактивні технологіi навчання; технологія модульного навчання; технологія проблемного навчання; дидактичні ігри.

Табл. 2. Літ. 10.

Liliya Bandura, Postgraduate Student, Precarpathian Vasyl Stefanyk National University

\section{PEDAGOGICAL CONDITIONS OF USING INNOVATIVE TECHNOLOGIES IN HIGH SCHOOLS' EDUCATIONAL PROCESS}

The article deals with the peculiarities of using the innovative technologies in higher education. The analysis of scientific and pedagogical literature and documents related to the topic of the work was performed. The basic criteria of humanistic education in the high school with using innovations are outlined. The article contains information about innovations and their place in the educational process today. Historical information about the origin of the term "innovative learning" is available. The stages of the "life" of pedagogical technologies are presented: from birth to their routineization. Terms of using technologies and their application in particular are presented. Amoung which interactive, modular and problem-based technologies, didactic games, etc. play an important role. An important role plays the emotional atmosphere, the psychological climate in the group during the class, interaction of all participants of the educational process, and using of the innovative technologies is the key to success in training. The most popular classifications of innovative technologies by different scientists have been worked out. In this article the new author's criteria for their classification are presented. The development will help university staff to choose the right pedagogical technology according to the purpose of the lesson. However, 